\title{
Nigeria: \\ Religious Conflict and the Boko Haram Crisis
}

\author{
Michael Aondona CHIANGI
}

\begin{abstract}
Religious conflicts have increased interfaith suspicion between Christians and Muslims in Nigeria with each group being determined to outshine the other in the propagation of its religious beliefs. In fact, even Islamic sect Boko Haram was formed on the belief in the superiority of Islam as a monotheistic religion and with a divine mandate to purge Islam of Western influences. This paper examines the complex issues surrounding the advent of the Boko Haram sect in Nigeria. It argues that religious conflict in Nigeria results from the propagation of radicalized exegeses and the use of religious sentiments for gain political advantage. Government's failure to act decisively also accounts for religious conflict in Nigeria and the Boko Haram in particular.
\end{abstract}

Keywords: Boko Haram, conflict, religion, ideology, violence, Islam.

\section{Introduction}

Religion plays a vital and significant role in the socio-political development of Nigeria. In fact, hardly can the Nigerian state ever be discussed without reference to the formidable and remarkable impact of religion. However, religion has, in a similar vein, largely exposed its negativities at various

Michael Aondona CHIANGI

Barrister and Solicitor

of the Supreme Court of Nigeria

Researcher at Talking About Terrorism, Washington DC, United States

E-mail: chiangimichael@gmail.com

Conflict Studies Quarterly

Issue 37, October 2021, pp. 3-20

DOI: $10.24193 / \mathrm{csq} \cdot 37.1$

Published First Online: 05 October /2021 times in the history of Nigeria. For instance, the Usman Danfodio led Jihad, the civil war propaganda (in which it was alleged that the secession of Biafra was owing to ethnic and religious differences), the pandemonium occasioned by Nigeria's inclusion in membership of the Organization of Islamic Conference (OIC) in 1986, and the incessant religious crises that have shaken the foundation of Northern Nigeria for many years. Some indelible examples of such crises include the 1987 religious violence between Christian and Muslim students at 
the College of Education Kafanchan, the religious crisis in Katsina in 1991, there was also another uprising in Kafanchan following the abduction of a Christian preacher by a Muslim group. In 2002, there was a religious riot in Kano as a protest against U.S. invasion of Afghanistan over Osama Bin Laden resulting in the death of 150 persons. Again, in 2007, some Muslim pupils killed their Christian teacher, Mrs. Oluwatoyin Olusesan, over the allegation that she had desecrated the Quran while attempting to stop a student from cheating in examination. All these demonstrate the extent to which religion could be easily deployed as a pliable tool for violent conflicts in Nigeria. These crises have consequently sown the seeds of bitter rivalry, suspicion and discord between Christians and Muslims everywhere in Nigeria. It is against the backdrop of these events that the Boko Haram sect was formed. The group was initially known for peaceful proselytization and non-violence but has now metamorphosed into a Jihadi faction fighting to establish an Islamic state in Nigeria.

\section{Epistemic foundation}

History has shown that religion has been used as a tool for social integration and unity in many societies. In the same vein, religion has also been used as an instrument of violence and conflict; hence it is a double-edged sword. At the turn of the 20th century, radical social scientist like Fredrick Engels, Karl Marx and Max Weber predicted the demise of religion and the imminence of secularism as an emerging paradigm. They contended that poverty, hardship and suffering makes religion a relevant social endeavour, thus, maintaining that religion should be completely eliminated because of its elusive relevance to genuine human happiness (Tucker, 1978).

These social scientists did not envisage the resurgence of religion in the era of modernization. The reason is that modernity promotes secularism and the complete emancipation of humanity from the shackles of the pervasive dominance of religion. However, the events that opened the 21st century, especially the spates of religious violence in many societies around the world, suggest the continued pre-eminence, perpetuity and persistence of religion as a formidable force directing human conduct to a great extent. This is further demonstrated by such religious based conflagrations as the 1979 Islamic revolution in Iran, the altercation between Muslims and Buddhists in Sri Lanka, the festering war in Sudan, the long standing Israeli-Palestine conflict, the Sunni-Shi'a war in Iraq and the Arab Spring, among others. Religious claims have become highly relativized due to contentious exegeses or the abundance of conflicting doctrines, and the ever-increasing idiosyncrasy of peoples' religious beliefs and practices which are nonetheless represented as true routes to salvation and which often lead to religious uprisings especially in societies lacking in religious tolerance.

Consequently, the apologists of secularism have strongly advocated for the elimination of religion as a public affair. In fact, secularization seems to suggest that even Christianity 
with its values centered on the promotion of Western education intrinsically promote intellectual anarchism which has spontaneously reduced the significance of religion in human affairs (Danjibo, 2012). For instance, Christians have been advised to give to Caesar what belongs to him and to God what is His. This explains why Christians are always careful not to mix secular matters with those of faith. As such, there is a clear chasm between the church and the secular state. It seems that Max Weber's "Protestant Ethic" has made significant impact on the rise of capitalism, especially in the 20th century which had inadvertently weakened the strength and efficacy of religion in the society amidst consumerism and hedonism (Weber, 1958). Karl Marx concluded that religion is the opium of the oppressed masses and that man must of necessity, be emancipated from this "estranged world of human objectification" (Tucker, 1978:111).

Samuel Huntington in his post-Cold War treatise, "Clash of Civilizations and the Remaking of the World Order" predicted that the evolution of the Arab world and the communist China would pose insurmountable challenges to Western civilization. He argued that, in spite of the powerful significance of Western Civilization, the Non-western societies have continued to oppose vigorously, the power of the West. In fact, Confucian and Islamic societies have attempted to expand their economic and military power resisting the "balance" against the West (Huntington, 2003). The West has, on the other hand, integrated its Islamic and Persian heritage into a secular framework that eliminates religious ideologies. This feat has not been recorded by the Muslims hence their conducts and lifestyles are still overtly influenced and largely modeled on the Sunnah (teachings and practices) of Prophet Mohammed and the symbolic significance of the Qur'an.

Indeed, Islam itself is interpreted to mean the total submission to the will of Allah, so it becomes difficult to separate Islam from the secular world since religion itself determines to a large extent everything about the life of a Muslim. Given this inflexible representation of Islam as a holistic device for the regulation of the entire lifestyle of its faithful, there is consequently no room for demarcation between spiritual and secular matters for devout Muslims. This view of Islam is characteristically held by the adherents of the Wahhabi or salafi sect of Islam. To them fundamentalism is an instrument for the sanitization of Islam which is alleged to have been infiltrated and corrupted by unorthodox practices associated with modernization (Achunike, 2008). While mainstream Salafis believe that preaching nonviolently, offering advice to politicians, and conducting educational activities can bring about a moral reorientation over a period of time, some versions of salafism encourage violent Jihad as an instrument of religious proselytization and revivalism. Thurston (2018), in describing Mohammed Yusuf's Salafi ideologies observed quite extensively as follows:

Yusuf not only advocated a singular interpretation of what he considered true Islam; he also demanded that Muslims choose, immediately, between Islam and a set of allegedly anti-Islamic practices: democracy, constitutionalism, alliances 
with non-Muslims, and Western-style education. Yusuf described his mission as one of purification, but, especially in the period leading up to the 2009 uprising, he added more militant language than other Nigerian Salafis used: "We call the Muslim community to correct its creed and its behaviors and its morals ... and to give children a correct Islamic education, then to undertake jihad in the way of Allah". Yusuf's stance had a rhetorical advantage over the positions adopted by other, non-jihadist Salafis: Yusuf's message was easier to understand, and the argumentation involved fewer steps (p. 96).

According to Yusuf, one simply had to choose between Islam and unbelief. Yusuf's rejection of democracy and Western-style schooling became Boko Haram's two most famous ideas. Yusuf preached against these two systems from the early 2000s. He grounded his stances in a set of interrelated doctrines that he took from Salafi scholarship. Yusuf's ultimate reference point, after the Qur'an and the hadith literature, was the Damascene theologian Ahmad Ibn Taymiyya (1263-1328), a central figure in Salafi thought. Even within Salafi circles, Ibn Taymiyya's legacy can be read in different ways, but Yusuf viewed him as a moral authority that brooked no compromise in creed or in applying Islamic law.

The propagation of similar separatist religious ideologies explains why religious conflagrations occur frequently in Muslim dominated parts of northern Nigeria. Prudence is however required to avoid stigmatizing all Muslims; more so as the proponents of this radicalized ideology form a sub-sect seeking global recognition in all Muslim societies. Thus, in order to fully demonstrate their piousness, fanatics of the wahabbi or salafi extraction respond with violence to any act which they regard as a violation of Sharia irrespective of the fact that other religious groups are correspondingly entitled to similar acts under the law.

Consequently, insidious and violent groups have sprung up in Nigeria at different times using different violent methods, including, but not limited to, acts of open terrorism, killing and kidnapping, as well as destruction of properties for the purpose of eradicating the 'harmful influence' of Western civilization. It is for this reason that the focal point of post-Cold War political interactions has been centered on the reconciliation and unification of conflicts between Western cultures and non-Western civilizations.

The aftermath of 9/11 witnessed a flood gate articles and academic analyses and has resurrected the question regarding the correlation between religion and violence. Religion has assumed a complex and multifaceted dimension due to ultraconservative ideologies especially the jihadist as represented in the ideology of the Boko Haram. 


\section{The Boko Haram sectarian crisis}

\section{(A) Evolution}

The origin of Boko Haram in Nigeria could be traced to as far back as 1945, when an Islamic scholar named Mohammed Marwa migrated from northern Cameroon and settled in Kano. While in Kano, Marwa became obsessed about the need to purify Islam. To him, Islam had been profaned by the influence of modernization and the evolution of the modern state structure (Danjibo, 2012). Marwa preached a millenarian, "Qur'an-only" doctrine that was far outside the northern Nigerian Muslim mainstream. His teachings were considered heretic and highly provocative especially his attitude towards the Emirate and other political institutions. This resulted in the expulsion of Marwa from Kano by the then Emir of Kano Alhaji Sanusi Lamido.

However, after the death of the Emir, Marwa returned to Kano and continued his abusive and provocative teachings in spite of resistance from security agencies. His preaching earned him the name "Maitatsine" which means "the one who curses others" and became the name of the sect. Maitatsine attracted a large number of followers mostly from the, "tallakawas" (the commoners) who could not afford the basic necessities of life. Maitatsine's social base also included rural migrants to northern cities, such as migrants from Niger, and possibly also Qur'an teachers and their students (Hiskett, 1987, p. 209). The group preached a strong compulsion to kill. They believe that if they are able to kill the "Arnas" (infidels) who do not believe in Allah, they would go to heaven. It was the preaching of this group that orchestrated the Maitatsine riot of 1980. The riot was however successfully suppressed to a standstill. Thurston (2018) described quite graphically, the events that culminated in the riot as follows:

The religious field was becoming more complicated throughout northern Nigeria. In the 1970s and after, alongside Salafi-Sufi rivalries and intra-Salafi competitions for influence, there was a broader rise in the diversity of Islamic religiosity in the north. Sometimes, activism took the form of fringe, violent movements. One was led by the Cameroon born Muhammad Marwa, nicknamed "Mai Tatsine", meaning "The One Who Curses". Marwa, based on and off in Kano after 1945, preached a millenarian, "Qur'an-only" doctrine that was far outside the northern Nigerian Muslim mainstream. He exhorted his followers to abandon modern technology. His group clashed with authorities in Kano in December 1980. Between four thousand and six thousand people were killed, including Marwa himself (p. 59).

Years after the extinction of the Maitasine, the former leader of Boko Haram, Mohamed Yusuf emerged. Yusuf was a secondary school drop-out who was studying the Qur'an in Niger and Chad. He returned to Nigeria and settled in Maiduguri where he began to preach. He believed that Western education has corrupted the society and so it should 
be moderated through Islamic scholarship. Thus, he began by establishing an Islamic school and a mosque. Meanwhile, Yusuf had developed the Wahhabi or salafist radical and fundamentalist Islamic ideologies while studying in Niger and Chad. He formed an Islamic sect known as "Jama at Ahl as-Sunnah Lid-da'wa wal-Jihad" meaning the "Congregation of the People committed to the propagation of Prophet's teachings and Jihad" which is known in Hausa language as "Boko Haram" Literally interpreted as "western education is forbidden".

In just a year, Yusuf had attracted more than 280.000 members across northern Nigeria and beyond. His followers drew their inspiration from the teachings of Maitatsine. Even though Maitatsine has been described as a direct forerunner of Boko Haram, it is more accurate to argue that Maitatsine is a movement merely having some demographic and structural similarities to Boko Haram. It is also important to stress the key theological differences between the two movements. Thus, unlike Boko Haram, Maitatsine lacked any connection to broader trends in Islamic thought such as Salafism or Jihadism. However, like Maitatsine, Yusuf preached provocatively and was highly dissident to constituted authority and the established teachings of other prominent Islamic scholars. Membership of this sect was initially drawn mostly from the "almajeris", the "tallakawas" (commoners), criminals and drug addicts. Boko Haram is argued to be an off-shoot of the defunct Maitatsine because it seeks to promote the same ideology of ultraconservative salafism as the Maitatsine did in the 1980s. The sect seeks to establish a "pure Islamic state" governed by Sharia and to put a stop to what it has described as 'westernization' (Newswatch 2009:6). Its modus operandi during the early years was the use of simply constructed weapons that required no advanced training against easily accessible targets (Valerie, 2012).

As a precursor to the large scale escalation of Boko Haram insurgency, some supporters of the group's leader had earlier orchestrated and coordinated attacks in Kannama village in Yobe state in 2003 (Thurston, 2011). A former leader of the Kanamma group, Aminu Tashen-Ilimi stated the objective of the uprisings quite unrepentantly:

Allah, the almighty Lord, has authorized every Muslim to fight to establish an Islamic government over the world. One day it will happen in Nigeria and everywhere.... I'm ready to take up arms. I don't know who gave us the name Taliban, I prefer 'mujahideen'; the fighters. I only know the Taliban in Afghanistan, and I respect them and what they did very much... Those who fought in Kannama and Gwoza are only Muslims who performed their holy duty. (Quoted in Thurston, 2018, p. 90)

The above quoted statement clearly confirms the group's resolve to wreak havoc on Nigerians in order to establish an Islamic state and how difficult it would be to deal with this calamity that has befallen Nigeria to date. 
In 2009, sectarian clashes erupted when an explosion occurred in Maiduguri in which one person was feared dead and several others wounded. While members of the sect attacked and burnt down police stations, churches, prisons and government institutions in the states of Borno, Bauchi, Yobe, Kano, and Adamawa; leaving hundreds of people dead and several others wounded, and more than 50 vehicles burnt. There were also reports that five primary schools were burnt and the headquarters of the Universal Basic Education also destroyed (Newswatch, 2009, p. 14). The headquarters of the Federal Road Safety Commission, the Police Command, and the National Population Commission including several vehicles were attacked and burnt down by the sect.

Meanwhile, more than 500 members of the Boko Haram sect were killed by security forces in Borno state. There were also reports from other parts of the North. In Bauchi state, it was reported that 41 persons were killed and several members of the sect wounded. In Kano, 300 members or sympathizers of the sect were restrained from wreaking havoc on a police station (BBC 2007). The police were said to have discovered a large quantity of arms and ammunition during a raid on the residence and mosque of one of their members. In Katsina state, Boko Haram attacked a police station but was sharply dislodged by the police and other members arrested. While in Sokoto, Kaduna, and Bauchi, the rate of havoc was quite moderate because security forces were alerted by events in Borno, Kano, and Adamawa States.

At the peak of the Maiduguri crisis, the leader of the sect, a 39-year old Mohammed Yusuf was arrested by security forces while trying to escape and later died (or as alleged, he was extrajudicially executed) in detention( BBC 2009). In the words of the then Governor of Bauchi state Isa Yuguda, their leader "rides exotic cars including expensive jeeps, has his children in choice private schools receiving sound and quality education, has private lawyers and doctors who treat and attend to him, yet he has the powers to indoctrinate people" (Newswatch, 2009, p. 19). This statement clearly shows that heretic religious teachings are capable of orchestrating violence in any society.

It is worthy of note that, in spite of the arrest of the sect's leader, its members continued to launch attacks at strategic locations in Nigeria. On the night of September 7, 2010, the group attacked a prison in Bauchi in an attempt to free some of its members who were then in custody. The attack resulted in the death of five prison guards; many prisoners who tried to escape including the sect's members were killed. Yet, an estimated 721 inmates were freed many of them suspected members of the sect who were arrested in connection with the 2009 uprising.

A month after the failed prison break, two attacks were launched in Maiduguri by members of the sect. On the $6^{\text {th }}$ of October, 2010 the group shot and killed two security guards at the home of Awana Ngala, the then leader of the All Nigerian Peoples Party (ANPP) and later that day he was also assassinated. Three days later, an Islamic cleric, 
Bashir Kashara was killed along with one of his students in Maiduguri. During this period, the attacks were sporadic and occasional because the members did not know what the arrest of their leader would portend. On December 24, 2010, there was an attack in a church in Jos, Plateau state in which 38 people were killed and the group later claimed responsibility.

It is to be noted that members of the sect had links with other transnational fundamentalist groups especially the Al-qaeda. The arrest of Yusuf and his father-in-law revealed that a large number of their members had been trained in the act of terrorism in Afghanistan, Lebanon, Pakistan and Iraq. In fact, rumours had it that when Osama Bin Laden was killed, some documents were recovered in his house one of which happened to be Abubakar Shekau's (Yusuf's successor) letter to Osama pledging his allegiance to him.

A few days after the uprising was repelled and the leader of Boko Haram was killed a member of the group was reported to have declared total war on Nigeria:

We have started a Jihad in Nigeria which no force on earth can stop. The aim is to Islamise Nigeria and ensure the rule of the majority Muslims in the country. We will teach Nigeria a lesson, a very bitter one... From the Month of August, we shall carry out series of bombing in Southern and Northern Nigerian cities, beginning with Lagos, Ibadan, Enugu and Port Harcourt... We shall make the country ungovernable, kill and eliminate irresponsible political leaders of all leanings, hunt and gun down those who oppose the rule of Sharia in Nigeria and ensure that the infidel does not go unpunished (Vanguard News, 2009).

The group went silent for some time and later resurfaced. This time Yusuf was succeeded by Abubakar Shekau, formerly his second-in-command. Under Shekau's leadership, the group continuously improved its operational capabilities and was thus heavily armed. Abubakar Shekau invoked Yusuf's ideas, adapting them to the group's new direction. There was strong rhetorical continuity between Yusuf and Shekau, especially given Yusuf's open embrace of jihadism in the final phase of his preaching. Shekau fit Yusuf's death neatly into the group's presentation of itself as the victim of state violence, rather than as the aggressor. Their first vehicle-borne explosive attack was carried out in June 2011, killing 6 persons at the Abuja police headquarters. In August the same year, Boko Haram bombed the United Nations office in Abuja, their first successful strike on a western target. In that attack, 11 UN staff and 12 visitors were killed and more than 100 injured (Ndahi, 2011).

Boko Haram has continued to launch steady attacks since 2011, striking a wide range of targets many times per week. Their attacks ranged from attacks on politicians, religious leaders, security forces and civilians. The effects of Boko Haram have been felt continuously in the whole of Northen Nigeria, Cameroun and have involved skirmishes 
along the borders of Chad and Niger. In Niger, the authorities did not really take any proactive steps in stemming the tide of the group's activities. In fact, Boko Haram was essentially believed to be a Nigerian problem. The government of Niger was however compelled to change its attitude to Boko Haram by 2014 when its threat became more deadly. The territorial expansion of the group towards the Niger border was accompanied by a new push to recruit hundreds of young Nigeriens (International Crisis Group, 2017). Boko Haram's activities range from kidnapping, continued trail of massacres and destruction of properties. The subsequent campaign of violence by Boko Haram culminated in a string of bombings across Nigeria.

The group strikes at anyone considered to be an enemy of Islam or anyone unfortunate to be present whenever the insurgent group decided to send their massage to the Nigerian government. The proliferation of attacks led to the declaration of a state of emergency by the then President Goodluck Jonathan in states where the menace was mostly felt during his tenure, when the crisis seemed to have reached a crescendo. However, in April 2014, the Boko Haram abducted 276 school girls from Government Secondary School in Chibock, Borno State. A few of them escaped, but majority of the remainder have not been released, instead Shekau, the leader of Boko Haram, announced his intention of selling them into sexual slavery (Ajao 2014). This was the incident that brought Boko Haram extended global attention. This abduction was in every sense a new and disturbing tactic in Boko Haram's operations which had generated contentious debates that are far reaching in global circles. Although in recent times the incumbent President Muhammadu Buhari had begun talks with members of the sect to secure the release of the abducted school girls. Some of the abducted students had been released but a majority of them are still in captivity.

In the same month of the abduction, a bomb was detonated in Abuja at a bus station in Nyanya claiming several lives. Elsewhere, Boko Haram continued to increase its presence in northern Cameroun. In May 2014, 10 Chinese workers were abducted. In July, the Cameroonian vice president's home village was attacked by about 200 militants; his wife was kidnapped along with the Sultan of Kolofata and his family. At least 15 people including soldiers and police officers were killed in the raid (BBC News, 2014b). Similar attacks continued till the dismissal of two senior military officers for incompetence by the Cameroonian president (BBC News 2014a).

\section{(B) Factions within Boko Haram}

Boko Haram has currently been divided into two factions - one led by Abubakar Shekau and the other led by Abu Abu Masab al-Barnawi (Olojo, 2019). However, Zenn (2016) has identified a third faction which is headed by one Mamman Nur although Nur was assassinated in August 2018. These factions have caused more havoc and appear to be more complicated than when Boko Haram first began. Al-Barnawi is the son late 
Muhammad Yusuf, the founder of Boko Haram. Like his father, his extremism is mild as compared to Shekau particularly with his liberal interpretation of who is liable to be killed. He supports attack on churches as a means of ending the "Christianization" of Muslim lands. But unlike Shekau, he is opposed to the killing of Muslims who do not actively oppose the Jihad. Al-Barnawi's faction is also focused on asymmetric attacks on military targets other than civilians and has orchestrated raids on military facilities in Nigeria, Niger, Cameroon and Chad. He is said to have more members than the other factions. In 2016 ISIL recognized al-Barnawi's faction as Islamic State West of Africa Province (ISWAP), and Shekau's faction was then referred to by its original name Boko Haram (McKenna n.d).

The leader of the third faction, Mamman Nur, before his death, did not belong to a defined group. Rather, he pulled together fighters from diverse factions to carry out complex operations. In 2011, it was reported that the attack on the UN office in Abuja was carried out by Mamman Nur's faction which involved elements of Boko Haram, Ansaru, AQIM and fighters returning from Al-shabaab in Somalia. Nur preferred to launch his attacks on international targets and churches.

Be that as it may, these violent acts have continued to plague the Nigerian Government and its citizens. The common argument in Nigeria is that this mayhem has been encouraged by the alarming level of corruption and underdevelopment, poverty and human rights violations as well as the dysfunctional security architecture in Nigeria.

\section{(C) Boko Haram and politics in Nigeria}

The politicization of sensitive issues has been a culture in Nigeria for many years. This practice has helped to frustrate all efforts geared towards combating religious conflicts in Nigeria. It is no doubt that the Boko Haram insurgency or Islamic militancy in general is primarily based on the desire to establish a global Islamic order which is driven by the belief in the notion that the West is constantly at war with Islam (Neumann, 2013). This reinforced by such international events as the Soviet invasion of Afghanistan in 1979, the Palestinian Intifada of 1987, the U.S.-led Gulf War of 1991 and invasions of Afghanistan in 2002 and Iraq in 2003, and media controversies such as the Danish caricatures of the Prophet Muhammad in 2006. These events were re-echoed in Nigeria, provoking protests by northern Muslims in some parts of the country. For some Muslims especially the Salafis, this global picture indicated that Islam was under severe attack by the West generally and Christianity in particular.

Yet, politics has also played a major role in the escalation of the Boko Haram sectarian violence and other religious crises in Nigeria. This is often linked to the long standing history of the socio-political imbalance between the north and the south. It could be recalled that before Nigeria's independence in 1960, British colonial authorities ruled the north and south separately. Western schools started by Christian missionaries flourished 
in the south but the northern leaders were ambivalent and even reluctant to allow the Christian missionaries to establish schools in the north for religious reasons. It could be recalled that not all Muslims were comfortable attending Western-style schools. Indeed, Boko Haram's hatred for Western education did not arise in a vacuum. Many Muslims in colonial northern Nigeria were afraid of sending their children to colonial schools because to them, it would convert their children into Christians or atheists, or would otherwise destroy their children's moral and intellectual foundations. Thus, the resultant effect was a massive economic and educational imbalance between the North and the South which persist to date.

At the peak of the Boko Haram crisis in 2014, it could be recalled that the Nigerian state was also preparing to conduct elections the following year. Consequently, Boko Haram became a tool in the hands of politicians either for propaganda or its eradication became a measure theme in most campaign promises. It is interesting to know that whereas those who used Boko Haram for propaganda were largely from the southern part of Nigeria, those who promised to eradicate Boko Haram were northerners. Indeed, even the main political parties during that period had sectional or ethnic/religious affiliation.

History has shown generally that politicians in Nigeria are known for using such militia groups for political and economic ends, only to discard them after they have served their purpose. It was reported that the former governor of Borno state, Amodu Sheriff in his bid to become the governor of the state in 2003, engaged youth support and support from figures who opposed the political status quo and were preaching the emergence of an Islamic state. The political atmosphere did not seem to favour him because his opponent appeared to be an anointed candidate of the Emir of Borno. Sheriff had to leverage on the Sharia debate to win his election. Sheriff approached Mohammad Yusuf seeking for support with the promise that Sharia would be fully introduced in Borno state. It was also reported that he employed a group of thugs named "ECOMOG" through the help of Yusuf to intimidate and scare voters away which enabled him manipulate and win the election. Thus in order to fulfill his side of the deal with Boko Haram, Amodu Sheriff established a Ministry of Religious Affairs and Special Education and appointed as Commissioner, one Buji Foi, who was widely identified as an associate and financier of Yusuf. Rumours had it that Foi siphoned funds from the state government and gave them to Yusuf, to enable him sponsor businesses for his followers and to accumulate weapons. When things got out of hand, Sheriff, in an Attempt to distance himself from Boko Haram years later, would tell reporters that his appointment of Foi into his government was because of Foi's prior experience in local government service, and not as part of a deal with Yusuf (Thurston, 2018, p. 109).

In the 2007 elections, Amodu Sheriff did not carry Boko Haram along because, apart from the power of incumbency which worked for him, he had close ties with the presidency in Abuja. Thus, for Yusuf and Boko Haram, the governor was regarded as a be- 
trayer, and even a threat to their mission. Consequently, Buji Foi resigned from Sheriff's government in 2007, reportedly over Sheriff's "failure to abide by the deal" with Boko Haram. Thenceforth, Yusuf's relations with authorities deteriorated. Boko Haram decided that whenever its members were arrested, it would attempt to free them by force.

In 2009, when Yusuf, Buji Foi (the former commissioner for religious affairs in Borno state) and Yusuf's father - law were killed, the authorities thought that it would end Boko Haram but it was rather the last straw that broke the camel's back. The attacks that followed the death of its leader moved from settling scores in Borno State into a wider campaign of terrorism, as the sect spoke out more and more on issues of national politics.

In 2012, a senior member of Boko Haram, Kabiru Sokoto, was found in the Borno State Governor's lodge in Abuja after escaping from police custody. No one knows what he was doing there. This incident happened the year after Senator Ali Ndume was arrested for aiding the group on the allegation that he telephoned militants more than seventy times in a month. All these events go to show that politicians have played a role in the escalation of this violent conflict.

The strategy of politicizing sensitive issues in Nigeria or even political intervention in similar issues has made Boko Haram a deeply complicated phenomenon and difficult to distil whether it is politics of calumny and vilification as usual or Islamic radicalism.

\section{(D) Ideology or failure of the government}

Several works on Boko Haram sectarian violence in Nigeria generally tend to limit the scope of this phenomenon to issues of religious fundamentalism and ideological fanaticism. This is actually the major issue.

In his lecture on $12^{\text {th }}$ June, 2009, Mohammad Yusuf, the founder of the Boko Haram sect counseled his members as follows:

Everything that you are asked to do, even if you will die, go and do it, do not come back and say: "When I went ...?" No! When you go, even if you will die, go and do it. Don't you see how they put bombs on people instructing them to leave, so they will go and explode? And yet they are happy. You should be like that. Whatever they forbid you from doing, even if you will die, do not do it (Kassim, 2017).

Historically, many Muslims have been brainwashed and made to believe that dying in the course of defending Islam would make them earn the status of a martyr. Therefore, they are ever willing and ready to sacrifice their lives through violent means as counseled by the leader of Boko Haram above. Thus, this "ethos of self-sacrifice and suicidal martyrdom" carried out in the name of God has grown exponentially in recent times with considerably higher levels of casualties (Hoffman 1998, p. 84). 
Yusuf's conviction was undoubtedly inspired by the ideology being promoted by leading Salafi scholars which he popularized after the Kannama uprising. Thus, while it is true that religious extremism is the main cause of Boko Haram, other factors have also helped to amplify and accelerate the insurgency.

Another challenge is the ubiquity of almajeri mostly in northern Nigeria. The almajeri are children sent by their parents to study the Qur'an under a malam (teacher). They roam the streets in major cities in Northern Nigeria, begging for alms and scavenging for food. Such children, because of their exposure to different forms of pressure, are potential sources of organized aggression. Thus, given their vulnerabilities, almajeri children are easy preys to radicalized and distorted religious beliefs. Whenever there is a riot in the northern states, these children become the foot soldiers deployed to perpetrate violence in the name of religion or for a token.

On the other hand, the general view of every average Nigerian is that both religious and sectarian violence is a product of the failure of government at various levels. The conditions under which Boko Haram emerged are akin to the socioeconomic conditions that served as a fertile ground for the breed of similar movements elsewhere. Conditions of living in Nigeria have grown from bad to worse; mass poverty, inequality in educational, political and employment opportunities, pervasive illiteracy arising from unemployment and corruption in high places. The misuse of funds earmarked for development has become a trend, thus leaving infrastructures to decay to the stage that they become irreparable. Life has become so difficult for Nigerians especially the youths who have to deal with societal pressure and reproach.

Furthermore, corruption has been particularly destructive in Nigeria. The political elites have failed to utilize the nation's wealth to effect positive changes to the lives of Nigerian citizens. This has created a disenchantment and frustration among Nigerians. Surprisingly, Nigeria is one of highest producers of petroleum in the world but where ironically many Nigerians live below one dollar a day. Northern Nigeria is the worst part hit by this predicament. A report made available by the National Bureau of Statistics in 2010 showed that the National poverty rate was $60.9 \%$, but it was $77.7 \%$ for north west and $76.3 \%$ for the north east compared with 59\% for south west (Lai, 2014). The failure to balance this economic disconnects between the north and the south is a pressing challenge that the Nigerian government must strive to overcome.

In addition, the vast regiment of unemployed youths mostly resident in cities have become available instruments for the prosecution of sectarian crisis. An idle hand they say is the devil's workshop. There were reports of graduates who tore their certificates and joined Boko Haram just to demonstrate the frustration of young people who left the university and could not secure any job after graduation. For such people, Western education will ever remain valueless as replicated in the Boko Haram sectarian ideology. 
A nation that allows its youth to be idle is said to be sitting on a time bomb because frustrated people seek relief from religion. When life becomes too miserable for a common man, the hope of redemption by religious men becomes an attractive alternative and any call to reform the society is ever keenly heeded, as many believe that the 'prophet who shall raise the nation to greater heights has come at last' (Adesoji, 2010).

Many Nigerians from the North thought that the proposed introduction of Sharia law was going to usher in a new and religious paradigm of public administration, allocation and distribution of resources. Unfortunately, the bad has become worse as some state governors (especially Amodu Sheriff of Borno state) who had keenly advocated and introduced Sharia as a state penal code were more interested in using religious sentiment to mobilize support for themselves and thus failed to deliver the services expected of them. Consequently, the North continues to deteriorate economically with the standard of living terribly plummeting. Thus the level of frustration and poverty among youths in the country becomes a fertile ground for the breed of violence of the kind perpetrated by Boko Haram.

Therefore, Boko Haram is partly associated with the failure of government at all levels to make the welfare of the citizenry a priority. The group might have seen this level of dilapidation and were bent on reversing the trend. To them, the protagonists of social, economic and economic dysfunction were leaders who had been trained in western-style schools. Western values and everything associated therewith was considered unconscionable and repugnant to the doctrines of Islam as it encouraged corruption, greed and laziness, thus Nigerians could not rely on it for the uplifting of the nation to greater heights.

The continued tension and the increasing suspicion between Christians and Muslims in Nigeria among other issues resulted in the declaration of the Sovereign National Conference in 2015 to discuss whether Nigeria should split or remain as a single entity.

\section{(E) Trivialization of early warning signs}

In spite of the virulent nature of religious-based conflicts, Nigerian governments have always treated issues of religion with flippancy and laxity. History has shown that security reports have always alerted the government on the degree of threats posed by religious extremism and radicalism, yet the government takes it for granted. It could be recalled that when the Maitatsine for instance emerged, the government did not immediately direct its attention to it. Rather the activities of the group were seen even by prominent politicians as a normal way of "spreading and defending the course of Islam". It was when the group leader Marwa began to arm his members with knives and deadly weapons that the government authorities became attentive to the belligerent modus operandi of the group. Reports indicated that members of the group were dissident to government authorities, ignored court orders and created "no-go areas" 
in some parts of Kano state. These set of activities were events that later culminated in the Maitatsine riot of 1980. Had the government responded preemptively, the conflict would not have erupted. A report of the tribunal of enquiry set up in 1980 by the Kano state Government concluded that:

"if there had been good and effective liaison between Local Authorities, Traditional Authorities, and the Police Force... this country would have been properly rid of him [Marwa] once and for all. Authorities of all stripes had been intimidated by the strength of Marwa's following" (Kano State Government Report, 1981).

The Boko Haram sect too, was initially repelled when the group was becoming a threat to Nigerians sometime in 2005 by security operatives in the states of Borno, Bauchi and Yobe. That was the famous "Operation Sawdust" which led to the arrest and detention of Mohamed Yusuf and Bello Maiduga under the regime of President Olusegun Obasanjo. They remained in detention until 2007 when the late President Yar' Adua assumed power. According to Danjibo (2012), some Muslim scholars and elites approached the president and lobbied for the release of the arrested radicals by persuading him to believe that these were just Islamic evangelists. This made the president to believe that the arrest and detention of the group's leader was not justifiable. Yar' Adua, immediately ordered for their release. Shortly after that, the group continued their radicalization and proselytization. There were early warning signs pointing to the violent potential of this group. In fact, reports were submitted to the government in Borno State for instance, and the Federal government pointing to the potential threats posed by the group. These reports and the perceived threats were sharply ignored by the government.

It was when reports further alleged that the group was making bombs that the government began to pay a closer attention to their activities, when unfortunately, the saga had escalated. Immediately, security agents were ordered to invade their premises and dislodge them. During the raid, an explosion took place killing a member of the sect. This resulted in violence which sharply spread over to other parts of northern Nigeria. Thus, if the government had responded immediately to both the Maitatsine and Boko Haram sectarian violence as well as other religious conflagrations that had occurred in Nigeria in the past, the result would not have been catastrophic.

\section{Concluding remarks}

Religion will forever remain a formidable force to reckon with in Nigeria. However, sectarian movements will similarly continue to engage the mind of the Nigerian state. It is imperative to note, that the rise of extreme religious groups in Nigeria is associated with the preposterous politicization of identity based conflicts, which has resulted in the erosion of a sense of common citizenship fostered by state contraction and popular disillusionment with local politics. Other incidental factors include socioeconomic 
grievances and widespread elite corruption clearly implicated in the ontology of the Boko Haram sectarian ideology.

Since its inception, Boko Haram has become an embodiment of insecurity, fear and suicide bombings. The group has emerged as the most violent religious sect in contemporary times. Boko Haram is not a novel phenomenon; rather, it is a microcosm of the broader range of political cum religious activism, revivalism and radicalization which has dotted the history of northern Nigeria since the Usman Danfodio-led jihad of the nineteenth century.

Thus, in order to effectively address the problem, the Nigerian Government has employed military strategy which is utterly undefined and may unlikely be able to achieve the aim which the present writer thinks, requires a deeper and sophisticated political engagement. Although this paper does not in any way, claim to have a grand strategy in combating religious conflict or Boko Haram in particular, a few important points will however suffice as a way forward.

First, elites in government at various levels should endeavour to deliver good and honest governance to the people. The evil effects of bad governance, corruption, total lack of security and welfare have all become attributed to those who govern. All leaders should demonstrate a commitment and desire to pursue the genuine ideals of democracy and accountable leadership. The group had rightly pointed out that the dysfunctional political system in Nigeria is a consequence of western values and orientation. Thus, Nigerians will continue to experience similar uprisings unless and until the government decides to show a strong commitment in reversing the contemporary paradigm or model of governance for the good of all.

Second, the clandestine elements that manipulate terrorist group for nefarious and selfish agenda should also be exposed without fear. In this regard, the media has a crucial role to play. Persons who have been arrested in connection with this saga should be thoroughly interrogated and prosecuted where necessary. On the other hand, Muslim intellectuals who are committed to the universal course of Islam should join hands to counter the narrow, bigoted, dogmatic and radicalized distortions of the purveyors of violence and terrorism.

A neo-religious educational praxis that would generate multi-religiosity in our youths should be the priority of relevant stakeholders, as well as a de-emphasis on faith-oriented curriculum which is overwhelmed by religious indoctrination and fanaticism. To this end, the curriculum of our religious instruction must necessarily be revisited in order to expunge those areas that are capable of triggering interfaith violence.

Conversely, persons who have been arrested in connection with religious violence should be made to go through a de-radicalization process to gradually eliminate the ideology of terror. There should also be an effective rehabilitation program for persons 
who have not just been brainwashed, but who also take religious combat as a normal way of expressing their religious commitment. If an effective rehabilitation program was initiated the remnants of the Maitasine would not have resurfaced as Boko Haram to propagate the same ideology.

Also, the political parties in Nigeria should endeavour to moderate their ideologies along the paths of patriotism rather than being tribal or religious, as this will facilitate the construction of a national philosophy. Efforts should therefore, be made to achieve a more cohesive political class by making political parties largely integrative.

Finally, it must be borne in mind, that the war against Boko Haram is the responsibility of everyone - government, business unions, civil society organizations, media, professionals and academics etc. All should endeavour to work towards a just and equitable Nigeria where tolerance and mutual respect will be highly recognized.

\section{References}

1. Achunike, H. (2008). Religious practices in Nigeria as a source of social conflict. Journal of Liberal Studies, 12 (1 \& 2), 286-295.

2. Adesoji, A. O. (2010). Restoring peace or waging war: Security agencies' management of ethno-religious uprisings in Nigeria. African Security Review, 19(3), 2-14.

3. Ajao, T. (2014, May 28). Boko Haram and the necessary state of emergency for transforming the intractable conflict in Nigeria. Sahara Reporters. Retrieved from http://saharareporters.com/2014/05/28/boko-haram-and-the-necessary-tate-ofemergency-for-transforming-the-intractable-conflict-in-nigeria.

4. BBC. (2007, April 17). Islamists Attack Nigeria Police. BBC News. Retrieved from http:// news.bbc.co.uk/2/hi/africa/6564629.stm.

5. BBC. (2009, July 31). Nigerian sect head dies in custody. BBC News. Retrieved from https://bbcnews.co.uk/2/hi/8177451.stm.

6. BBC. (2014a, July 30). Cameroon army officers sacked after Boko Haram attacks. BBC News. Retrieved from https://www.bbc.com/news/world-africa-28563715.

7. BBC. (2014b, August 6). Islamic Militants Kill 10 in Northern Cameroun. BBC News. Retrieved from https://bbcnews.com/news/world-africa-28684302.

8. Danjibo, N. D. (2012). Islamic fundamentalism and sectarian violence: The Maitatsine and Boko Haram crisis in Northern Nigeria. Institute of African Studies.

9. Hiskett, M. (1987). The Maitatsine riots in Kano, 1980: An assessment. Journal of Religion in Africa, 17(3), 209-223.

10. Hoffman, B. (1998). Inside Terrorism. Columbia University Press.

11. Huntington, S. P. (2003). The clash of civilizations and the remaking of the world order. Simon and Schuster Paperbacks.

12. Kano State Government (1981). Report of the Kano Disturbances Tribunal of Inquiry. The Government Printer

13. Kassim, A. (2017, August 19). Shaykh Aminu Daurawa: Boko Haram and the theological discourse on suicide bombing. Medium. Retrieved from https://ak61.medium.com/ 
shaykh-aminu-daurawa-boko-haram-and-the-theological-discourse-of-suicidebombing-a8e5941c5035.

14. Lai, M. (2014, September 11). Politicization of Boko Haram insurgency, bane of Nigeria's anti-terror fight. Vanguard. Retrieved from https://www.vanguardngr. com/2014/09/politicisation-boko-haram-insurgency-bane-nigerias-anti-terrorfight-lai-mohammed/.

15. McKenna, A. (n.d). Boko Haram: Nigerian Islamic Group. Enclopedia Britanica. Retrieved from https://www.britannica.com/topic/Boko-Haram.

16. Neumann, P. R. (2013). The trouble with radicalization. Journal of International Affairs, 89(4), 873-893.

17. Ndahi, M. (2011, August 28). UN house bombing: Why we struck - Boko Haram. Vanguard. Retrieved from https://www.vanguardngr.com/2011/08/un-house-bomb ing-why-we-struck-boko-haram/amp.

18. Newswatch. (2009, August 10). The Boko Haram Crisis in Maiduguri. Newswatch Magazine, 1-25.

19. Olojo, A. (2019, July 2). Dialogue with Boko Haram: Back on the Agenda?. Institute for Security Studies. Retrieved from https://issafrica.org/iss-today/dialogue-with-bokoharam-back-on-the-agenda?utm_source=BenchmarkEmail\&utm_campaign=ISS_ Today\&utm_medium=email.

20. Thurston, A. (2011a). A comprehensive look at the history of attacks by Nigeria's Boko Haram. The Christian Science Monitor. Retrieved from http://www.csmonitor. com/2011/0701/A-comprehensive-look-at-the-history-of-attacks-by-nigerias-bokoharam

21. Thurston, A, (2018b). The history of an African Jihadist movement. Princeton University Press.

22. Tucker, R. C. (1978). The Marx-Engel reader. Scribner.

23. Valerie, T, (2012). Boko Haram and Islamic fundamentalism in Nigeria. Global Security Studies Summer, 3(3), 46-60.

24. Vanguard. (2009, August 14). Boko Haram resurrects, declares total Jihad. Vanguard News. Retrieved from http://www.vanguardngr.com/2009/08/boko-haram-ressurec ts-declares-total-jihad/.

25. Weber, M. (1958). Protestant ethics and the spirit of capitalism. Roxbury.

26. Zenn, J. (2016). Making sense of Boko Haram's different factions: Who, how and why?. African Arguments. Retrieved from https://africanarguments.org/2016/09/20/mak ing-sense-of-boko-harams-different-factions/. 